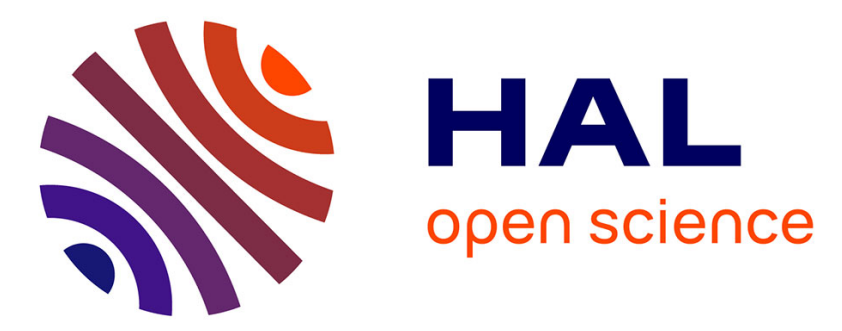

\title{
Robust Organocatalysts for the Cleavage of Vegetable Oil Derivatives to Aldehydes through Retrobenzoin Condensation
}

Nam Duc Vu, Souleymane Bah, Elsa Deruer, Nicolas Duguet, Marc Lemaire

\section{- To cite this version:}

Nam Duc Vu, Souleymane Bah, Elsa Deruer, Nicolas Duguet, Marc Lemaire. Robust Organocatalysts for the Cleavage of Vegetable Oil Derivatives to Aldehydes through Retrobenzoin Condensation. Chemistry - A European Journal, 2018, 24 (32), pp.8141-8150. 10.1002/chem.201800091 . hal02128568

\section{HAL Id: hal-02128568 \\ https://hal-udl.archives-ouvertes.fr/hal-02128568}

Submitted on 3 Jun 2021

HAL is a multi-disciplinary open access archive for the deposit and dissemination of scientific research documents, whether they are published or not. The documents may come from teaching and research institutions in France or abroad, or from public or private research centers.
L'archive ouverte pluridisciplinaire HAL, est destinée au dépôt et à la diffusion de documents scientifiques de niveau recherche, publiés ou non, émanant des établissements d'enseignement et de recherche français ou étrangers, des laboratoires publics ou privés. 


\title{
Robust organocatalysts for the cleavage of vegetable oil derivatives to aldehydes through retro-benzoin condensation
}

\author{
Nam Duc Vu, Souleymane Bah, Elsa Deruer, Nicolas Duguet* and Marc Lemaire*
}

\begin{abstract}
A series of thiazolium salts was prepared and tested for the cleavage of the $\alpha$-hydroxyketone derived from methyl oleate. The robustness of these precatalysts was determined by dynamic thermogravimetric analyses (TGA). It has been shown that the stability of these species is mainly governed by the nature of the counter-anion and some of them were found stable until $350-400^{\circ} \mathrm{C}$. The $\alpha$-hydroxyketone derived from methyl oleate was cleaved under reactive distillation conditions using optimized, thermally robust $\mathrm{N}$ butylthiazolium triflate to give the cleavage product, namely, nonanal and methyl azelaaldehydate, with 85 and $70 \%$ yields. A range of $\alpha$ hydroxyketones derived from several fatty acids was cleaved to give the corresponding bio-based aldehydes with up to $98 \%$ isolated yields. Finally, this protocol was successfully applied to a high-oleic sunflower oil derivative.
\end{abstract}

\section{Introduction}

Vegetable oils and animal fats (triglycerides) are attractive renewable raw materials for the chemical industry. ${ }^{[1]}$ Indeed, their competitive cost and wide availability (about 202 million tons in 2015) ${ }^{[2]}$ make them adequate for numerous high-volume commercial applications. For instance, they can be used as biofuel $^{[3]}$ (biodiesel) but can be best converted to valuable building blocks for applications in pharmaceuticals, cosmetics, paints, coatings, packaging materials, lubricants, surfactants, fine chemicals and polymers. ${ }^{[4]}$ Most of the reactions on oleochemicals occur at the fatty acid carboxy group and they are comparatively few examples on the alkyl chain. However, the presence of double bond(s) in unsaturated fatty acid derivatives allows the installation of a range of organic functions ${ }^{[5]}$ including aldehyde ${ }^{[6]}$ epoxide, ${ }^{[7]}$ diol, ${ }^{[8]}$ ketone and diketone, ${ }^{[9]} \alpha$ hydroxyketone ${ }^{[10]}$ carbonate, ${ }^{[11]}$ among others. ${ }^{[12]}$ More importantly, cleavage reactions - mainly using methyl oleate as archetype - can give access to building-blocks with higher added-value, essentially for surfactants and polymer applications. In this respect, the formation of fatty mono- and difunctionalized aldehydes is of great interest as they can be

[a] N. D. Vu, S. Bah, E. Deruer, Dr N. Duguet, Pr M. Lemaire Univ Lyon, Université Claude Bernard Lyon1, CNRS, INSA, CPELyon, Institut de Chimie et Biochimie Moléculaires et

Supramoléculaires, ICBMS, UMR 5246, Equipe CAtalyse, SYnthèse et ENvironnement (CASYEN), 43, bd du 11 novembre 1918, F69622 Villeurbanne cedex, France.

Fax: +33(0)-472-431-408; phones: +33(0)-472-448-507, +33(0)-472431-407.

E-mails: nicolas.duguet@univ-lyon1.fr, marc.lemaire.chimie@univlyon1.fr

Supporting information for this article is given via a link at the end of the document. used for a broad variety of transformations. For example, linear aldehydes can be used for the preparation of bio-based surfactants through reductive alkylation of polyols. ${ }^{[13]}$ Moreover, functionalized aldehydes can be transformed to monomers for the preparation of polyesters and polyamides through reduction or reductive amination, respectively. ${ }^{[8]}$ However, there are not so many methods to produce aldehydes from vegetable oils or fatty acid derivatives. Thermal cracking of methyl ricinoleate obtained from castor oil produces bio-heptanal as a co-product of nylon11 (Rilsan ${ }^{\circledR}$ ) synthesis. ${ }^{[14]}$ This route is very specific to ricinoleic derivatives and requires elevated temperature $\left(>300^{\circ} \mathrm{C}\right)$. Crossmetathesis of unsaturated fatty acid derivatives with ethylene (ethenolysis) $^{[15]}$ produces terminal alkenes that can be further transformed to the corresponding homologated aldehydes through carbonylation. ${ }^{[16]}$ This sequence is very attractive from a green chemistry point of view but implies the use of gases and requires specialized high-pressure equipments. Other reported routes involve the formation of oxidized intermediates that are cleaved to the desired aldehydes (Scheme 1). Reductive ozonolysis of fatty acid derivatives provides aldehydes with excellent atom-economies. ${ }^{[17]}$ However, this method requires the use of ozone $\left(\mathrm{O}_{3}\right)$ which is highly toxic and involves the formation of explosive ozonide intermediates. Moreover, the generation of ozone is a highly energy-intensive process, that also constitutes a serious drawback. Alternatively, fatty epoxides or diols, which are also industrially relevant oleochemicals, can be also cleaved to aldehydes but only using $\mathrm{HIO}_{4}$ or $\mathrm{NalO}_{4}$ as stoichiometric oxidants, ${ }^{[18]}$ respectively. In this context, new methodologies should be developed to produce fatty aldehydes to guarantee their use in biobased products.

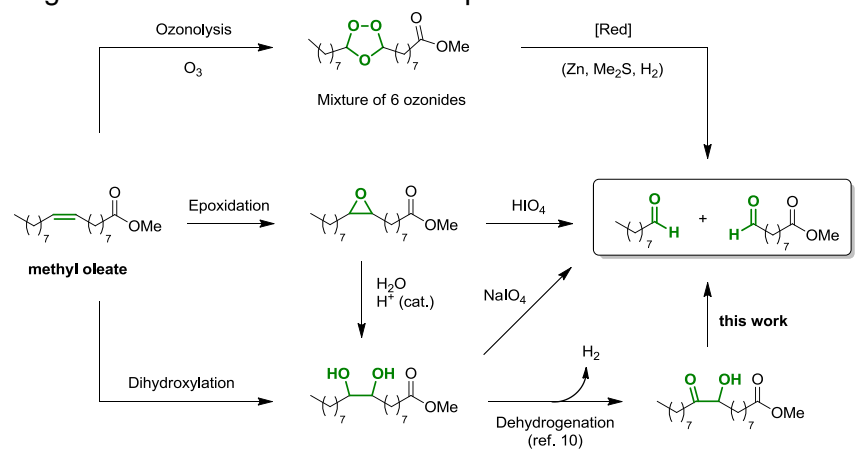

Scheme 1. Main routes to fatty aldehydes from methyl oleate.

Enzymatic catalysis occupies a pivotal place in the utilization of biomass as renewable feedstock as enzymes are inherently involved in both biosynthetic or biodegradation pathways. Most enzymes produce aldehydes in protected or masked forms (carbohydrates) or use them as transient intermediates. One of 
these enzymes is the transketolase (TK) (EC 2.2.1.1). This thiamine diphosphate (ThDP)-dependent enzyme is involved in the metabolism of carbohydrates. Indeed, TK catalyzes in vivo the formation of D-glyceraldehyde 3-phosphate from D-xylulose 5 -phosphate (aldehyde donor) through the transfer of a twocarbon ketol unit (glycolaldehyde) to D-ribose 5-phosphate (aldehyde acceptor) to give D-sedoheptulose. ${ }^{[19]}$ However, the synthetic utility of this transformation is limited due to the reversibility of the process. Some strategies have employed hydroxypyruvic acid as the ketol donor to render the transformation irreversible but free aldehydes could not be produced through these methods. ${ }^{[20]}$

The analogous organocatalyzed process, i.e. the chemical formation of aldehydes from the corresponding $\alpha$-hydroxyketone is called "retro-benzoin condensation". Contrary to the (asymmetric) benzoin condensation that was extensively studied using cyanides, thiazolium salts and related $\mathrm{N}$-Heterocyclic Carbenes (NHCs), ${ }^{[21]}$ only little attention has been paid to the opposite process. ${ }^{[22]}$ Miyashita et al. were the first to synthetically exploit the retro-benzoin condensation for the preparation of ketones from $\alpha$-substituted benzoins. ${ }^{[23]}$ The reaction was catalysed either by cyanide ion or NHCs. In that case, the equilibrium of the reaction was shifted towards the formation of ketones, probably thanks to their higher stability. More recently, Chi et al. have reported a bio-inspired approach for the generation of formaldehyde equivalents from carbohydrates through a retro-benzoin process catalysed by a thiazolium salt. ${ }^{[2]}$ The reactive formyl anion equivalent was reacted with enones to give $\beta$-formylketones, thus exploiting the irreversible character of the Stetter reaction to shift the equilibrium of the reaction. However, free aldehydes could not be isolated through the use of these two methodologies.

In this context, we have previously reported the cleavage of the $\alpha$-hydroxyketone derived from methyl oleate to aldehydes through a retro-benzoin process catalyzed by a thiazolylidene species. ${ }^{[25]}$ We have shown that the aldehydes produced are in equilibrium with their corresponding acyloins. The free aldehydes, i.e. nonanal and methyl azelaaldehydate, were recovered by reactive distillation under vacuum and were isolated with poor yields.

We now report here an efficient, robust catalytic system based on a thiazolium salt that allows the cleavage of a series of $\alpha$-hydroxyketones derived from vegetable oils with high yields.

\section{Results and Discussion}

We have previously identified that only thiazolium salts were efficient precatalysts for the cleavage of the $\alpha$-hydroxyketone derived from methyl oleate. This observation is in accordance with the work of $\mathrm{Chi}^{[24]}$ who has also proved the superiority of thiazolium salts (over imidazolium, imidazolinium and triazolium salts) to promote the cleavage of carbohydrate derivatives through a retro-benzoin process.

In the quest for an efficient catalytic system, we have first screened a range of commercially available and structurally diverse thiazolium salts (Table 1). First, $\alpha$-hydroxyketone 1 was treated with thiamine pyrophosphate (ThPP) 6, thiamine hydrochloride (vitamine $\mathrm{B} 1 . \mathrm{HCl})$ 7. $\mathrm{HCl}$ and thiamine-derived thiazolium salt 8 in the presence of $\mathrm{K}_{2} \mathrm{CO}_{3}$ at $150^{\circ} \mathrm{C}$ under microwave irradiation. ${ }^{[26]}$

Table 1. Screening of commercially available thiazolium salts. ${ }^{[a]}$

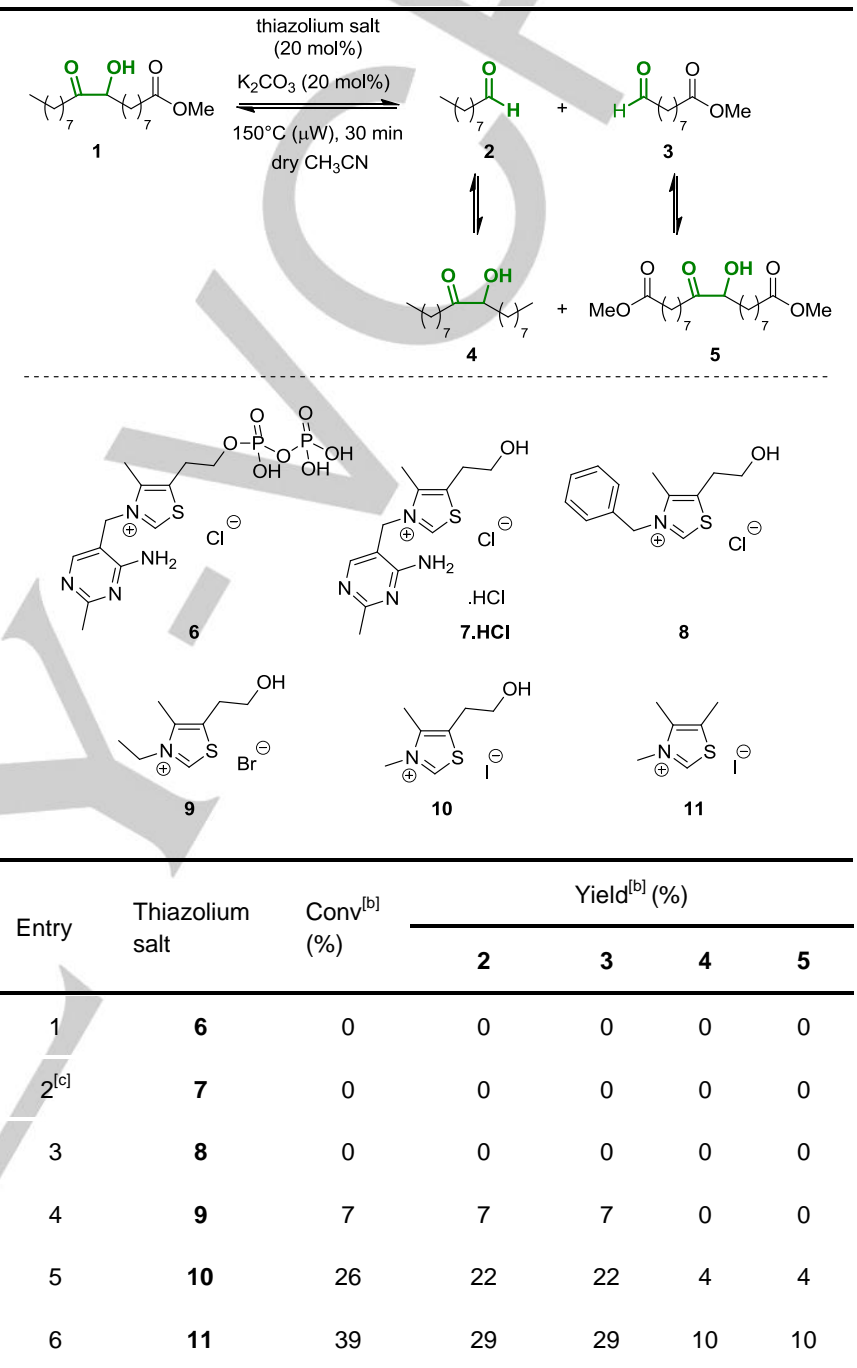

[a] Conditions: Microwave tube, $\alpha$-hydroxyketone 1 (1:1 mixture of regioisomers, $0.2 \mathrm{mmol}$ ), thiazolium salt (20 mol\%), $\mathrm{K}_{2} \mathrm{CO}_{3}(20 \mathrm{~mol} \%)$, dry $\mathrm{CH}_{3} \mathrm{CN}(2 \mathrm{~mL}), 150^{\circ} \mathrm{C}(\mu \mathrm{W}), 30 \mathrm{~min}$. [b] Determined by $\mathrm{GC}$ using hexadecane as internal standard. [c] $40 \mathrm{~mol} \%$ of $\mathrm{K}_{2} \mathrm{CO}_{3}$ were used in this case.

Under these conditions, no conversion of the starting material was observed showing the inability of these catalysts to promote this retro-benzoin process (Table 1, entries 1-3). This could be attributed to the degradation of these catalysts under the reaction conditions. For example, despite that 7 is stable until about $200^{\circ} \mathrm{C}$ as a salt, ${ }^{[27]}$ it could quickly degrade at moderate temperature in organic basic solution. ${ }^{[28]}$ With thiamine-derived precatalysts 9 and 10 , the conversion increased from $7 \%$ with $N$ ethyl derivative 9 to $26 \%$ with precatalyst 10 bearing a $N$-methyl 
substituent (Table 1, entries 4-5). These results clearly indicate that the steric bulkiness of the catalyst is deleterious for the activity. Finally, when using less sterically demanding thiazolium 11, the conversion reached $39 \%$ and the aldehydes and their corresponding acyloins were formed with 29 and $10 \%$, respectively (Table 1 , entry 6 )

A range of various solvents was next tested under standard conditions using thiazolium 11 (20 mol\%), $\mathrm{K}_{2} \mathrm{CO}_{3}(20 \mathrm{~mol} \%)$ at $150^{\circ} \mathrm{C}$ under microwave irradiation for 30 minutes (Table 2). DMF and EtOAc gave moderate conversion compared to $\mathrm{CH}_{3} \mathrm{CN}$ while non-polar solvents such as toluene and heptane were not found suitable to efficiently promote the reaction (Table 2, entries 1-5). Ethereal solvents such as THF, 2Me-THF, MTBE and DBE were also screened but gave poor results (2-6\% conversion) (Table $\mathrm{S} 1$ in ESI). Finally, methyl stearate was investigated as bio-based solvent but no conversion was observed under these conditions and $\alpha$-hydroxyketone 1 was recovered unaltered (Table 2 , entry 6 ).

Table 2. Solvent screening. ${ }^{\text {[a] }}$

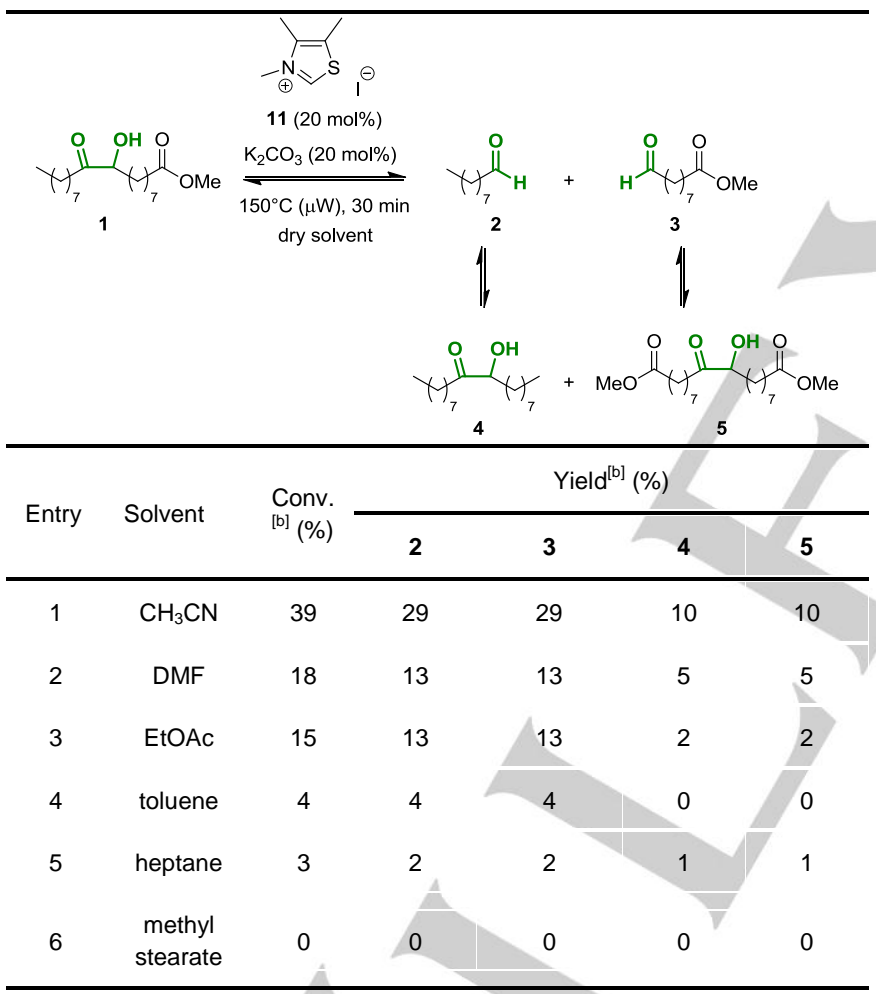

[a] Conditions: Microwave tube, $\alpha$-hydroxyketone $1 / 1: 1$ mixture of regioisomers, $0.2 \mathrm{mmol}$ ), thiazolium 11 (20 mol\%), $\mathrm{K}_{2} \mathrm{CO}_{3}(20 \mathrm{~mol} \%)$, dry solvent $(2 \mathrm{~mL}), 150^{\circ} \mathrm{C}(\mu \mathrm{W}), 30 \mathrm{~min}$. [b] Determined by $\mathrm{GC}$ using hexadecane as internal standard. THF = tetrahydrofuran, $2 \mathrm{Me}-\mathrm{THF}=2$ methyl tetrahydrofuran, MTBE $=$ methyl tert-butylether, DBE = dibutylether, DMF $=$ dimethylformamide.

The catalyst loading was next probed at $150^{\circ} \mathrm{C}$ using optimal thiazolium salt 11 (Figure 1). Expectedly, when increasing the loadings of both the thiazolium salt and the base from 2 to $20 \%$, the conversion increased from 7 to $39 \%$ and the yields of the desired aldehydes improved to $29 \%$ (Table S2 in ESI). These

results could not be significantly improved using $40 \mathrm{~mol} \%$, indicating that a plateau is reached (Figure 1).

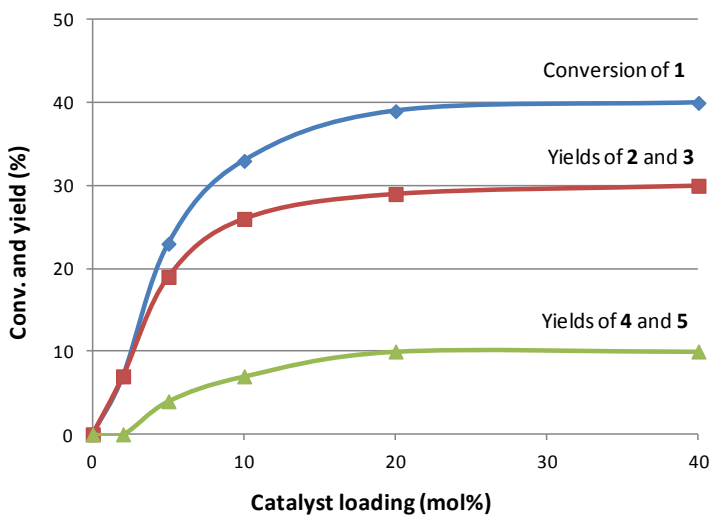

Figure 1. Influence of catalyst loading on conversion and yields. Reaction conditions: Microwave tube, $\alpha$-hydroxyketone 1 (1:1 mixture of regioisomers, $0.2 \mathrm{mmol})$, thiazolium $11, \mathrm{~K}_{2} \mathrm{CO}_{3}$, dry $\mathrm{CH}_{3} \mathrm{CN}(2 \mathrm{~mL}), 150^{\circ} \mathrm{C}(\mu \mathrm{W}), 30 \mathrm{~min}$. The conversion of $\mathbf{1}$ (blue diamonds), yields of aldehydes $\mathbf{2}$ and $\mathbf{3}$ (red squares) and yields of $\alpha$-hydroxyketones $\mathbf{4}$ and $\mathbf{5}$ (green triangles) were determined by GC using hexadecane as internal standard.

Nevertheless, at $170^{\circ} \mathrm{C}$, the conversion reached $56 \%$ after 30 minutes and was further improved to $60 \%$ after 1 hour. Under these conditions, aldehydes 2-3 and acyloins 4-5 were formed with $40 \%$ and $20 \%$ yields, respectively (Table S2 in ESI). However, the synthetic utility of this methodology is limited due to the fact that the whole system is in equilibrium. That is the reason why, the cleavage of $\alpha$-hydroxyketone 1 was carried out by reactive distillation in order to shift the equilibrium towards the formation of aldehydes 2 and 3 . This strategy should also prevent the formation of symmetrical acyloins $\mathbf{4}$ and $\mathbf{5}$. Thus, thiazolium salt 11 (10 mol\%) was treated with $\mathrm{K}_{2} \mathrm{CO}_{3}(10 \mathrm{~mol} \%)$ in $\mathrm{CH}_{3} \mathrm{CN}$ for $10 \mathrm{~min}$ at $25^{\circ} \mathrm{C}$. The resulting solution was transferred to a distillation flask containing the starting material and $\mathrm{CH}_{3} \mathrm{CN}$ was removed in vacuo. Then, neat $\alpha$-hydroxyketone $1(4.00 \mathrm{~g})$ was heated at $180^{\circ} \mathrm{C}$ (oil bath) and the aldehydes were simultaneously distilled (Scheme 2 ).

$$
\text { 1) } \mathrm{CH}_{3} \mathrm{CN}, 25^{\circ} \mathrm{C}, 10 \mathrm{~min}
$$

$$
\underbrace{\mathrm{O}}_{1(4.00 \mathrm{~g})} \mathrm{O}_{7}^{\mathrm{OH}} \mathrm{OMe}
$$

2) removal of $\mathrm{CH}_{3} \mathrm{CN}$

$\longleftarrow$

3) $180^{\circ} \mathrm{C}, 3$ hours vacuum $=4-6 \mathrm{mbar}$ neat

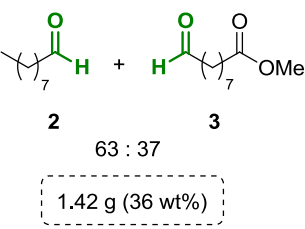

Scheme 2. Recovery of aldehydes by reactive distillation

The distillation stopped after 3 hours and aldehydes 2-3 were recovered with $36 \mathrm{wt} \%$ combined yield as a $63: 37 \mathrm{GC}$ ratio 
(Figure 2). Satisfyingly, the residue showed no significant sign of degradation and starting material $\mathbf{1}$ and acyloin $\mathbf{5}$ were recovered with 64 wt\% combined yield as a 95:5 GC ratio (see Figure $\mathrm{S} 1$ in ESI).

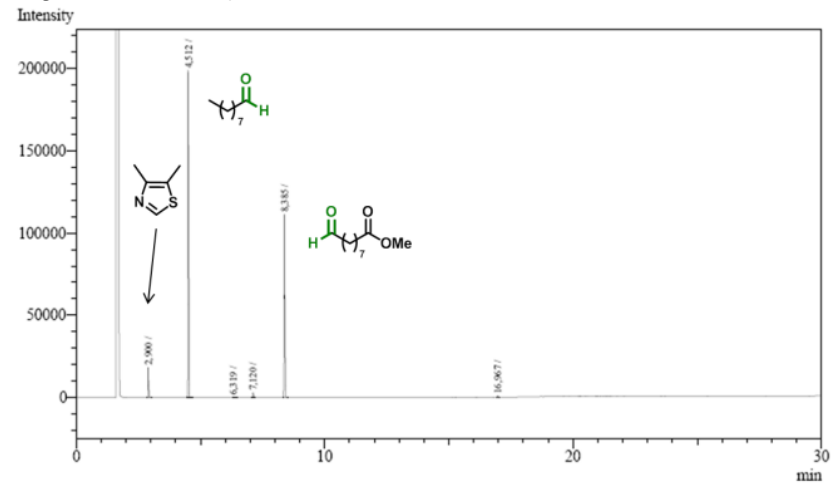

Figure 2. GC chromatogram of the distillate.

These results were encouraging but the yield of aldehydes could not be improved after a prolonged time. We hypothesized that the catalyst has been deactivated or degraded during the reactive distillation under these conditions. This hypothesis has been confirmed by the presence of 4,5-dimethylthiazole - a catalyst fragment - on the GC chromatogram of the distillate (peak at $2.90 \mathrm{~min}$, Figure 2). We proposed a catalyst degradation pathway to account for the formation of this catalyst byproduct. On the one hand, the active thiazolylidene species could be protonated (e.g. by the $\mathrm{OH}$ group of the $\alpha$ hydroxyketone) and the released nucleophile could react with the activated $N$-methyl group to give 4,5-dimethylthiazole (Scheme 3, a).

a: degradation from the thiazolylidene species

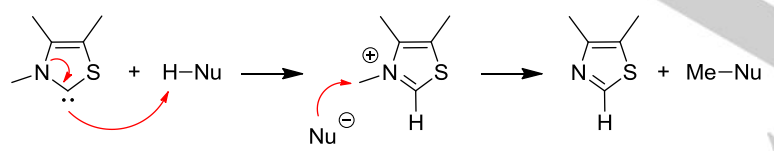

b: degradation from the thiazolium pre-catalyst

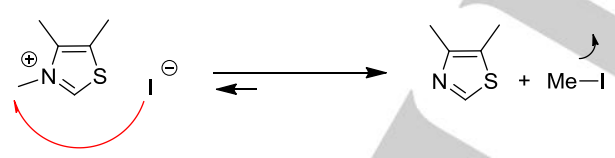

Scheme 3. Proposed catalyst degradation pathway.

On the other hand, the degradation could directly occur from the thiazolium iodide, that could be still present in the reaction mixture due to incomplete deprotonation. In that case, the iodide ion could attack the activated $\mathrm{N}$-methyl group to cleave the C-N bond leading to 4,5-dimethylthiazole and iodomethane (Scheme 3 , b). This degradation pathway, known as the reverse Menshutkin reaction, is quite well established for imidazolium halide salts. ${ }^{[29]}$ In our case, the degradation process is accelerated under vacuum since iodomethane is volatile and its elimination shifts the equilibrium of the reaction. ${ }^{[30]}$ For further optimization, the preliminary deprotonation will be avoided as it usually shortens the life time of the catalyst and the thiazolium salt will be used as a reservoir for the thiazolylidene active species.

Structural modifications of the initial precatalyst have been made in order to increase its stability. Two strategies have been envisioned: i) to increase the length or the bulkiness of the $\mathrm{N}$ alkyl group, ii) to reduce the nucleophilicity of the couter-ion. The thiazolium salts were prepared either from 4,5-dimethylthiazole by direct alkylation with a range of alkyl halide $(\mathrm{I}, \mathrm{Br})$ or pseudohalide (OTf) or from thiazolium iodide $\mathbf{1 1}$ by anion metathesis using silver or lithium salts of charge-delocalized soft anions (see ESI). All the thiazolium salts $\mathbf{1 1 - 2 4}$ prepared in this study are presented in Figure 3.

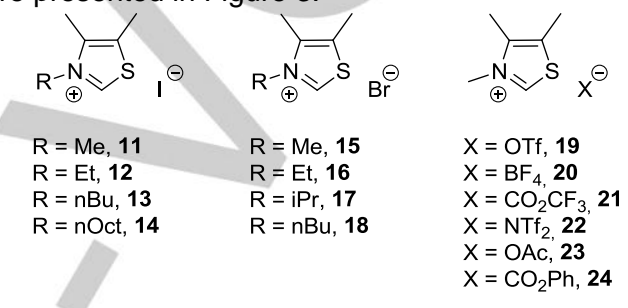

Figure 3. Thiazolium salts used as precatalysts in this study.

It should be noted that thiazolium acetate $\mathbf{2 3}$ was specifically prepared in order to install a basic counter-ion that could prevent the use of external base for the generation of the free carbene. However, even if this compound has been characterized by ${ }^{1} \mathrm{H}$ NMR (see ESI), the product degrades quickly at room temperature. The thermal decomposition of imidazolium carboxylates has already been reported but these species were found stable until $100-200^{\circ} \mathrm{C} .^{[31]}$ The fact that thiazolium acetate 23 readily degrades at room temperature has been attributed to the fact that thiazolium protons are more acidic than their imidazolium counterparts. As a result, the acetate anion has been replaced by a benzoate anion and the corresponding thiazolium benzoate $\mathbf{2 4}$ was prepared. Interestingly, the salt crystallizes with one molecule of benzoic acid and the structure has been confirmed by single-crystal X-ray diffraction (Figure 4 and Figure $\mathrm{S} 2$ in $\mathrm{ESI}$ ).

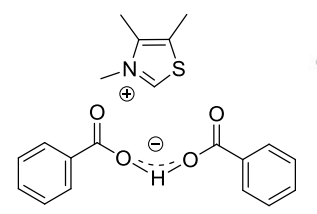

24. $\mathrm{PhCO}_{2} \mathrm{H}$

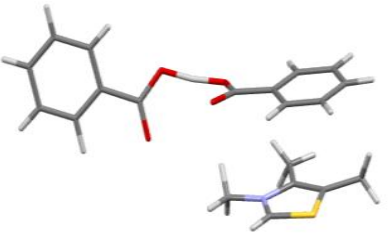

Figure 4. X-ray diffraction of thiazolium benzoate $24 . \mathrm{PhCO}_{2} \mathrm{H}$.
The activity of the synthesized thiazolium salts has been evaluated in the retro-Benzoin condensation of the $\alpha$ hydroxyketone 1 . The influence of the alkyl chain length was first probed using a range of thiazolium iodides (Table 3). 
Table 3. Catalytic tests using thiazolium iodides. ${ }^{[a]}$

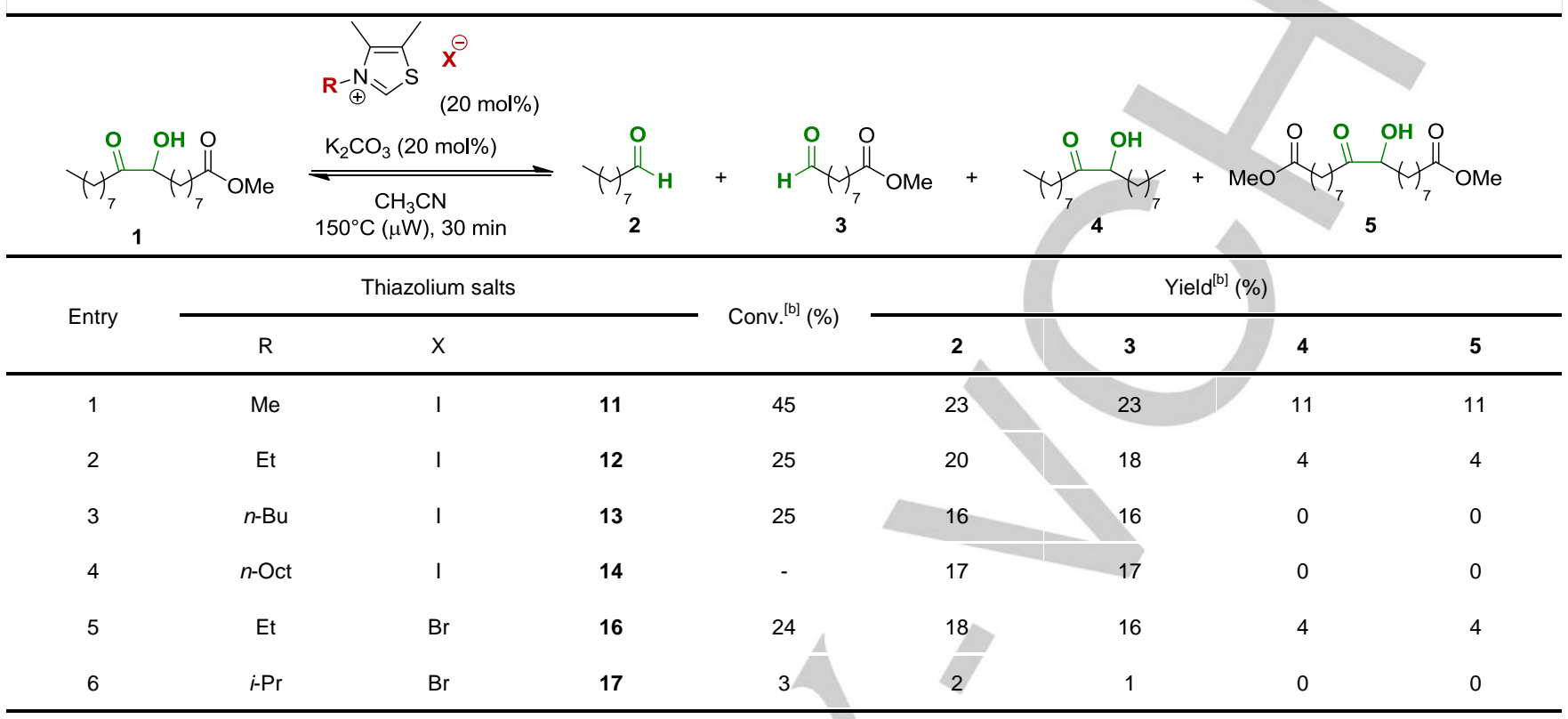

[a] conditions: microwave tube, $\alpha$-hydroxyketone 1 (1:1 mixture of regioisomers, $0.2 \mathrm{mmol})$, thiazolium salts $(0.04 \mathrm{mmol}), \mathrm{K}_{2} \mathrm{CO}_{3}(0.04 \mathrm{mmol})$, dry $\mathrm{MeCN}(2$ $\mathrm{mL}), 150^{\circ} \mathrm{C}, 30 \mathrm{~min}$. [b] Yields were determined by GC using $\mathrm{n}$-hexadecane as internal standard.

The increase of the alkyl chain length led to a drop of conversion from $45 \%$ with $\mathrm{N}$-methyl substituent to $17 \%$ with $\mathrm{N}$-octyl (Table 3 entries 1-4). Similarly, the yields of aldehydes 2-3 and acyloins 4-5 dropped from 23 to $16 \%$ and from 11 to $0 \%$, respectively. With thiazolium 17, almost no conversion was observed indicating that a bulky group is deleterious for the activity of the catalyst (Table 3, entry 6). From these results, thiazolium iodide 11 was found the best catalyst and was selected for further optimization. The influence of the anion of a range of $\mathrm{N}$-methylthiazolium salts was next investigated (Table 4). Using I, Br, $\mathrm{CF}_{3} \mathrm{SO}_{3}(\mathrm{OTf}), \mathrm{BF}_{4}$ and $\mathrm{CF}_{3} \mathrm{CO}_{2}$ anions, the conversion of $\alpha-$ hydroxyketone 1 reached around $34-39 \%$ and the yields of aldehydes 2-3 and acyloins 4-5 established around $23-29 \%$ and
8-10\%, respectively (Table 4 , entries $1-5$ ). Therefore, and not surprisingly, the nature of the anion has little impact on the catalytic activity as the latter arises from the corresponding $\mathrm{N}$ methyl-thiazolylidene species. However, the conversion is much higher $(52 \%)$ with thiazolium triflimide 22 , indicating that this catalyst also promotes side-reactions (Table 4, entry 6). Thiazolium benzoate 24. $\mathrm{PhCO}_{2} \mathrm{H}$ also catalyzes the retrobenzoin condensation but afforded lower yields (Table 4, entry 7). Interestingly, the reaction also proceeds without external base showing the ability of the benzoate ion to act as an internal base for the generation of the active thiazolylidene species (Table 4, entry 8).

Table 4. Catalytic tests using $N$-methyl-thiazolium salts. ${ }^{\text {[a] }}$

Entry




\begin{tabular}{|c|c|c|c|c|c|c|c|}
\hline 3 & $\mathrm{CF}_{3} \mathrm{SO}_{3}$ & 19 & 39 & 26 & 24 & 10 & 10 \\
\hline 4 & $\mathrm{BF}_{4}$ & 20 & 35 & 23 & 23 & 10 & 10 \\
\hline 5 & $\mathrm{CF}_{3} \mathrm{CO}_{2}$ & 21 & 34 & 25 & 25 & 9 & 9 \\
\hline 6 & $\left(\mathrm{CF}_{3} \mathrm{SO}_{2}\right)_{2} \mathrm{~N}$ & 22 & 52 & 21 & 18 & 3 & 3 \\
\hline 7 & $\mathrm{PhCO}_{2}$ & 24. $\mathrm{PhCO}_{2} \mathrm{H}$ & 30 & 15 & 14 & 3 & 3 \\
\hline $8^{[c]}$ & $\mathrm{PhCO}_{2}$ & 24. $\mathrm{PhCO}_{2} \mathrm{H}$ & 36 & 20 & 17 & & 4 \\
\hline
\end{tabular}

[a] Conditions: microwave tube, $\alpha$-hydroxyketone 1 (1:1 mixture of regioisomers, $0.2 \mathrm{mmol})$, thiazolium salts $(0.04 \mathrm{mmol}), \mathrm{K}_{2} \mathrm{CO}{ }_{3}(0.04 \mathrm{mmol}), \mathrm{dry} \mathrm{MeCN}(2 \mathrm{~mL})$, $150{ }^{\circ} \mathrm{C}, 30 \mathrm{~min}$. [b] Yields were determined by GC using n-hexadecane as internal standard. [c] No base was used in this condition.

The thermal stability of most of the precatalysts was evaluated by dynamic thermogravimetric analysis (TGA). Even if this method overestimates the thermal stability, it usually provides useful information on the short-term thermal stability of ionic liquids and is generally used for comparative purposes. ${ }^{[32]}$ Moreover, contrary to imidazolium-based ionic-liquids, few TGAs were reported on thiazolium derivatives. ${ }^{[33]}$ First, the influence of the alkyl chain length on the stability has been probed with a range of thiazolium iodides 11-14 and dynamic TGAs were measured under nitrogen at a heating rate of $20^{\circ} \mathrm{C} \cdot \mathrm{min}^{-1}$ (Figure 5). Several thermal properties including $T_{\text {onset }}$ and $T_{\text {peak }}$ are gathered in Table S3 in ESI.

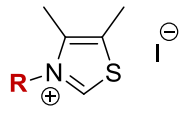

Dynamic TGA of thiazolium iodides (under $\mathrm{N}_{2}$ )

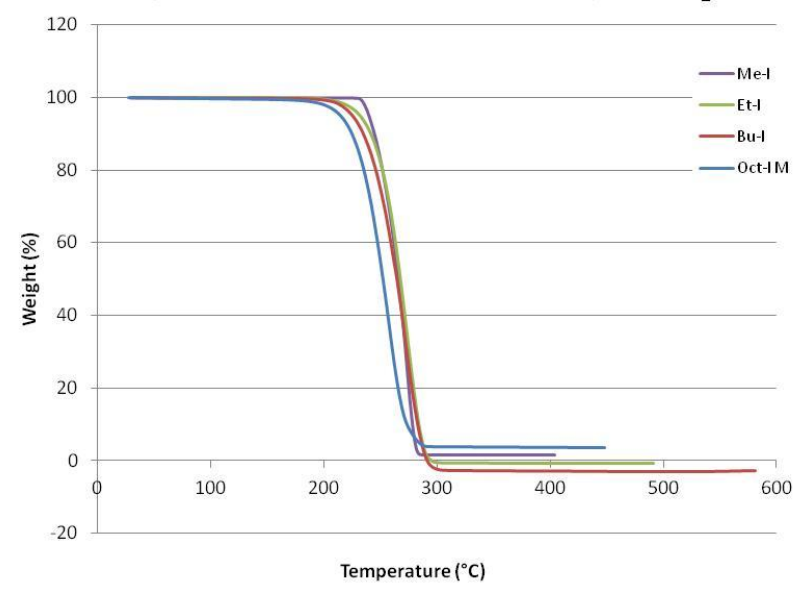

Figure 5. Dynamic TGA curves of thiazolium iodides.

The thermal stability of thiazolium salts is not significantly affected with the increase of the alkyl chain length from methyl to $n$-octyl as the dynamic TGA curves are almost superimposed. However, slight differences can be observed on the $T_{\text {onset }}$ that is decreasing with the increase of the alkyl chain length (Table S5 in ESI). These results are in accordance with the behavior of imidazolium-based ionic liquids. ${ }^{[34]}$ Then, the influence of the anion on the thermal stability has been probed with a range of $\mathrm{N}$-methyl-thiazolium salts (Figure 6).

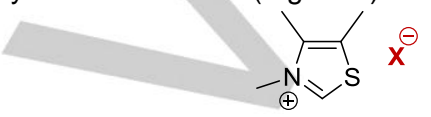

Dynamic TGA of Me-thiazolium salts (under $\mathrm{N}_{2}$ )

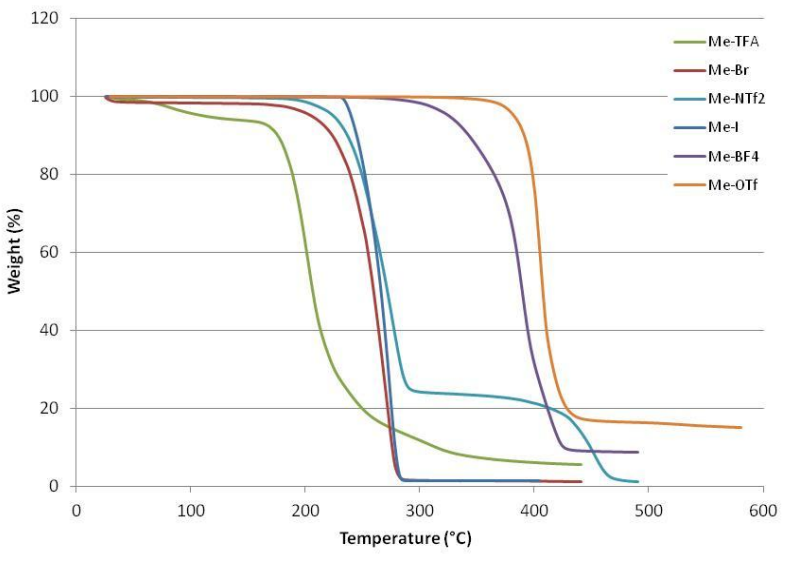

Figure 6. Dynamic TGA curves of $N$-methyl-thiazolium salts.

In this case, the thermal stability of thiazolium precatalysts is considerably affected by the nature of the anion. Halide anions such as I and $\mathrm{Br}$ display very similar behavior with comparable $\mathrm{T}_{\text {onset, }} \mathrm{T}_{\text {peak }}$ and $\mathrm{T}_{\text {endset }}$ (Table S5 in ESI). In sharp contrast, stabilized fluorinated anions present huge differences. While $\mathrm{CF}_{3} \mathrm{CO}_{2}$ anion reduces the thermal stability compared to halides, the use of $\mathrm{BF}_{4}$, OTf and $\mathrm{NTf}_{2}$ anions increases the decomposition temperature to at least $100^{\circ} \mathrm{C}$. Noteworthy, the $\mathrm{NTf}_{2}$ anion, which is usually giving the best thermal stabilities in the imidazolium series, showed two degradation waves in our case. This could be probably explained by two different mode of degradation, one from the thiazolium cation and other one from the $\mathrm{NTf}_{2}$ anion. These results show that the overall thermal stability of thiazolium salts is mainly governed by the nature of the anion and the relative robustness of these species could be ranked as follows: OTf $>\mathrm{BF}_{4}>\mathrm{NTf}_{2}>\mathrm{I}>\mathrm{Br}>\mathrm{CF}_{3} \mathrm{CO}_{2}$. Finally, thiazolium triflate 19 was found to be the more stable precatalyst with a degradation temperature of about $395^{\circ} \mathrm{C}$. 
The cleavage of $\alpha$-hydroxyketone 1 under reactive distillation conditions was re-investigated using thiazolium triflate 19 that was selected as the best catalyst in terms of stability and activity (Table 5). Thus, neat $\alpha$-hydroxyketone 1 was heated at $180^{\circ} \mathrm{C}$ in the presence of thiazolium salt $19(20 \mathrm{~mol} \%)$ and $\mathrm{K}_{2} \mathrm{CO}_{3}(10$ $\mathrm{mol} \%$ ) and the aldehydes were simultaneously distilled under reduce pressure (1-3 mbar). Pleasingly, the distillate was recovered with an overall $75 \mathrm{wt} \%$ yield after only 15 minutes and the yields of aldehydes $\mathbf{2}$ and $\mathbf{3}$ were calculated to 84 and $70 \%$, respectively (Table 5 , entry 1 ). However, we have noticed that some of thiazolium 19 has been sublimated under these conditions. In order to prevent such inconvenience, $n$-butyl analog 25 has been synthesized (see ESI) and used in the same reaction. Satisfyingly, aldehydes $\mathbf{2}$ and $\mathbf{3}$ were recovered with similar results and no sign of sublimation has been observed (Table 5, entry 2). Decreasing the temperature to $160^{\circ} \mathrm{C}$ led to similar proportions of aldehydes but the overall yield dropped to $70 \mathrm{wt} \%$ (Table 5, entry 3). A crude sample of $\alpha$-hydroxyketone 1 (83\% GC purity) was also used as starting material and the aldehydes 2 and 3 were recovered with 85 and $71 \%$ yields, based on the purity of the starting material (Table 5 , entry 4 ). These results highlight the robustness of the catalytic system developed.

Table 5. Cleavage of a-hydroxyketone 1 under reactive distillation conditions. ${ }^{\text {[a] }}$

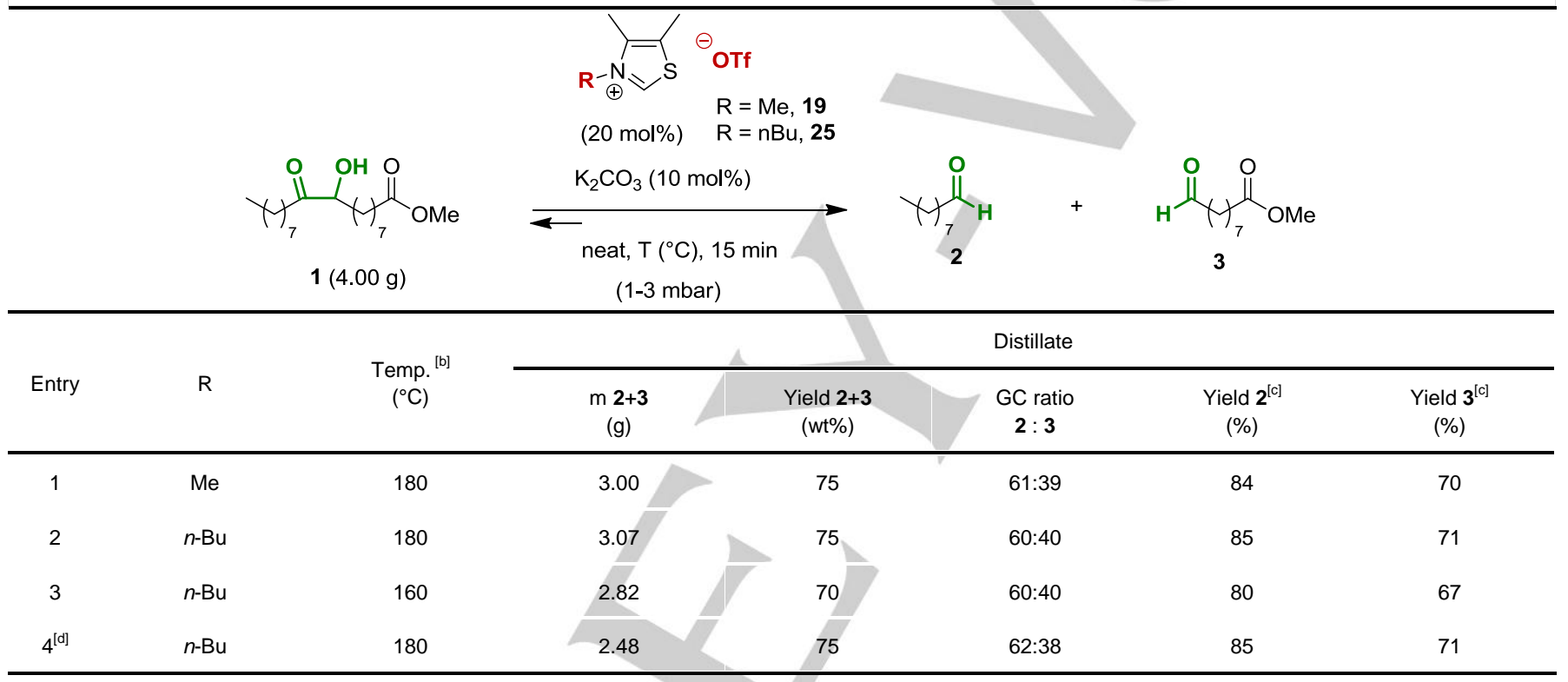

[a] Conditions: distillation set-up, $\alpha$-hydroxyketone 1 (1:1 mixture of regioisomers, $4.00 \mathrm{~g})$, thiazolium salt $(20 \mathrm{~mol} \%), \mathrm{K}_{2} \mathrm{CO}_{3}(10 \mathrm{~mol} \%)$, neat, $1-3 \mathrm{mbar}, 15 \mathrm{~min}$. [b] Temperature of the oil bath. [c] Calculated yields based on calibration. [d] Crude starting material containing $\alpha$-hydroxyketone 1 (83\%), the corresponding diketone (5\%), the corresponding diol (3\%) and nonanoic acid (about 6\%).

The scope of the cleavage of $\alpha$-hydroxyketones derived from vegetable oils has been next investigated using the previously optimized conditions (Table 6). These fatty $\alpha$-hydroxyketones were prepared from the corresponding diols, either by oxidation using a homogeneous palladium-neocuproine complex or by dehydrogenation using a heterogeneous ruthenium catalyst. ${ }^{[10 a]}$ Symmetrical $\alpha$-hydroxyketones $\mathbf{4}$ and $\mathbf{5}$, derived from selfmetathesis products of methyl oleate ${ }^{[35]}$ gave nonanal $\mathbf{2}$ and methyl azelaaldehydate 3 with 88 and $80 \%$ isolated yields, respectively (Table 6 , entries $1-2$ ). This protocol was also applied to other fatty acid derivatives. Unsymmetrical $\alpha$ hydroxyketones $\mathbf{2 6}$ and $\mathbf{2 8}$ derived from butyl and 2-ethylhexyl oleate gave nonanal 2 with 82 and $93 \%$ yield, respectively (Table 6, entries 3-4). In these cases, the remaining bifunctional aldehydes could not be distilled due to their high boiling point and undergo NHC-catalysed self-benzoin condensation.
Consequently, symmetrical acyloins 27 and 29 were isolated from the residue by column chromatography and were obtained with 39 and $54 \%$ yields, respectively. Similarly, $\alpha$-hydroxyketone $\mathbf{3 0}$ derived from methyl erucate gave nonanal $\mathbf{2}$ with an excellent $98 \%$ yield and symmetrical acyloin $\mathbf{3 1}$ was isolated from the residue with $30 \%$ yield (Table 6 , entry 5 ). The $\alpha$-hydroxyketone 32 derived from methyl ricinoleate was next cleaved to give $(R)$ 3-methoxynonanal $\mathbf{3 3}$ and aldehyde $\mathbf{3}$ but only poor yields were obtained (Table 6, entry 6). We hypothesized that the methoxy group was bulky enough to prevent the addition of the $N$-butyl catalyst 25 onto the carbonyl group. For that reason, the reaction was repeated with $\mathrm{N}$-methyl catalyst 19 . Satisfyingly, the yields of aldehydes $\mathbf{3 3}$ and $\mathbf{3}$ improved to 15 and $30 \%$, respectively (Table 6 , entry 6 , results in brakets). However, these results are not as good as those obtained previously. In fact, due to the presence of the methoxy group, the starting 
material 32 exists as a mixture of four inseparable isomers $($ NMR ratio $=25: 18: 21: 36)$, i.e. two diastereoisomers for each regioisomer. It is likely that one of these species reacts faster than the others with catalyst $\mathbf{1 9}$ to give the cleavage compounds thus leading to some regio- or diastereoselection. This could also explain why some starting material was recovered from the residue. Tris( $\alpha$-hydroxyketone) 34, prepared from high-oleic sunflower oil ( $85 \%$ oleic acid content) and containing about $60 \%$ of $\alpha$-hydroxyketone functionality, was also subjected to the cleavage conditions (Table 6, entry 7). Remarkably, nonanal 2 was obtained with $25 \%$ yield $(25 \%$ with thiazolium 19 ) indicating that challenging substrates such as triglycerides could be also cleaved under the current conditions. This opens the possibility to valorize waste vegetable oils to value-added aldehydes, that could be used as such or for the preparation of bio-based surfactants. Moreover, bifunctional aldehydes and symmetrical acyloins obtained through this methodology could be also used as building-blocks for the preparation of bio-based polyesters and polyamides. Finally, to further demonstrate the interest of this methodology, benzoin $\mathbf{3 5}$ was cleaved under reactive distillation conditions (Table 6, entry 8). Satisfyingly, benzaldehyde $\mathbf{3 6}$ was obtained with $90 \%$ isolated yield, thus showing the versatility of the method developed.

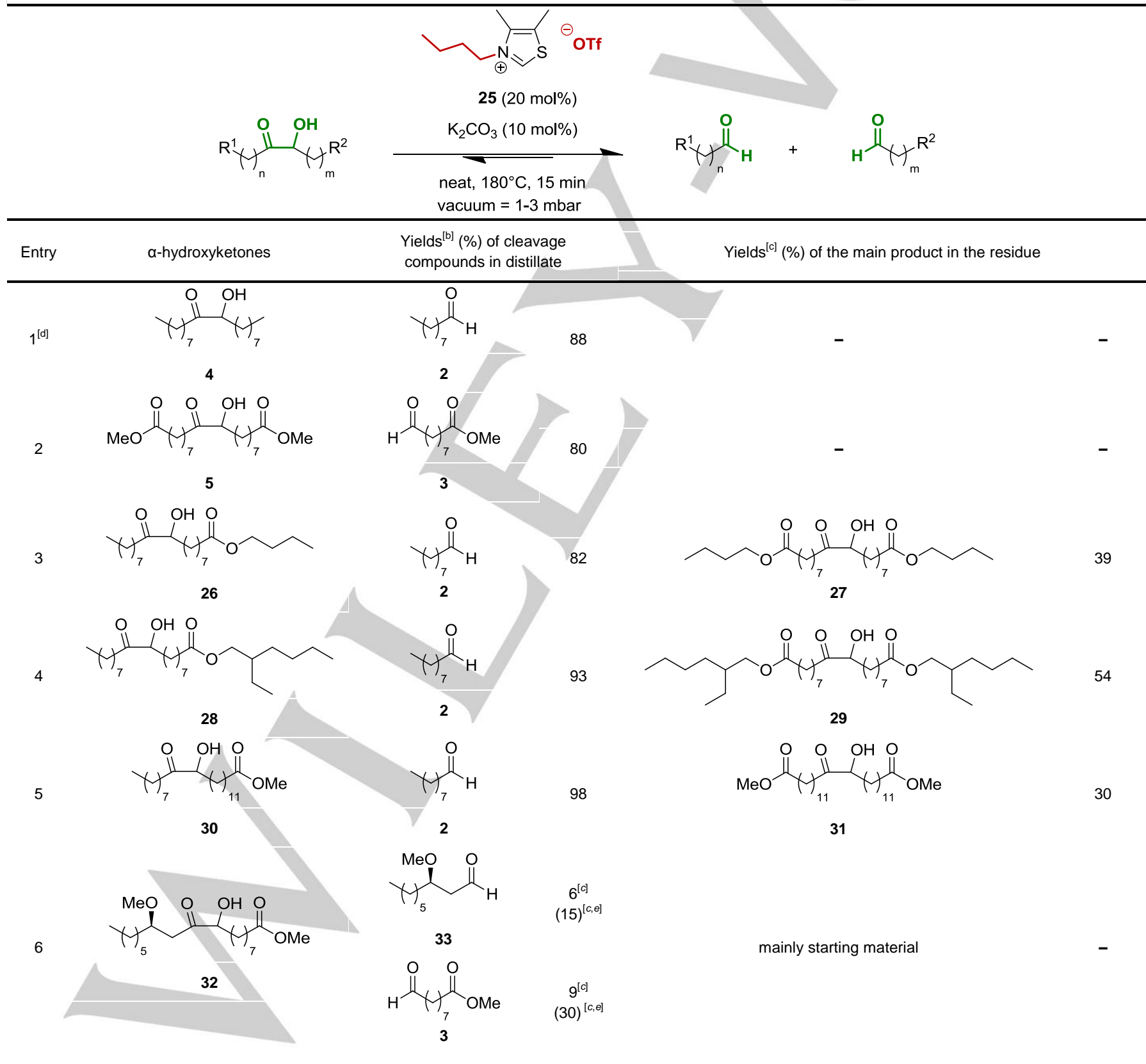




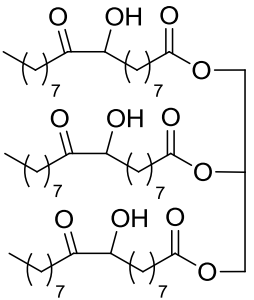

34

$8^{[\mathrm{f}}$<smiles>O=C(c1ccccc1)C(O)c1ccccc1</smiles>

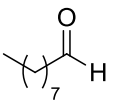

2
25

$(25)^{[e]}$

90

35<smiles>O=Cc1ccccc1</smiles>

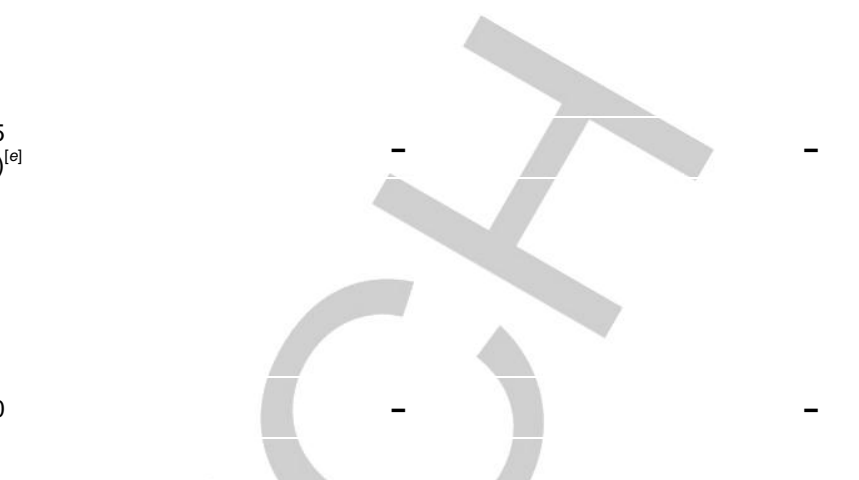

[a] Conditions: distillation set-up, $\alpha$-hydroxyketone (1:1 mixture of regioisomers), thiazolium salt ( $20 \mathrm{~mol} \%), \mathrm{K}_{2} \mathrm{CO}_{3}(10 \mathrm{~mol} \%)$, neat, $180^{\circ} \mathrm{C}$ (oil bath temperature), vacuum = 1-3 mbar, $15 \mathrm{~min}$. [b] Isolated yields. [c] Isolated yields after purification by column chromatography. [d] The vacuum pressure was set at $10 \mathrm{mbar}$ to avoid the distillation of the starting material. [e] Yield in brackets was obtained using catalyst 19. [f] The vacuum pressure was set at 50 mbar.

\section{Conclusions}

In conclusion, we have developed a robust catalytic system based on thiazolium salts for the cleavage of the $\alpha$ hydroxyketone derived from methyl oleate. The reaction proceeds through a retro-benzoin process under reactive distillation conditions. The cleavage products, namely, nonanal and methyl azelaaldehydate, were obtained with 85 and $70 \%$ yields, respectively. A range of $\alpha$-hydroxyketones derived from several fatty acids has been also cleaved to give the corresponding bio-based aldehydes with up to $98 \%$ isolated yields. Finally, this protocol was also found applicable to a higholeic sunflower oil derivative, opening the possibility to valorize waste vegetable oils. The aldehydes produced through this methodology are excellent platforms for the preparation of biobased surfactants or building-blocks for polymer applications.

\section{Experimental Section}

General procedure for the thiazolylidene-catalysed cleavage of $\alpha$-hydroxyketone under microwave conditions: In a $5-\mathrm{mL}$ microwave tube, 9(10)-hydroxy-10(9)-oxooctadecanoate 1 (1:1 mixture of regioisomers) $(65.7 \mathrm{mg}, 0.2 \mathrm{mmol}, 1$ equiv), the thiazolium salt $(0.04 \mathrm{mmol}, 20 \mathrm{~mol} \%)$ and $\mathrm{K}_{2} \mathrm{CO}_{3}(5.5 \mathrm{mg}$, $0.04 \mathrm{mmol}, 20 \mathrm{~mol} \%$ ) were added. The tube was flushed with argon and dry $\mathrm{CH}_{3} \mathrm{CN}(2 \mathrm{~mL})$ was added. The mixture was stirred under microwave irradiation at the desired temperature for a period of time. The mixture was cooled down to room temperature and analyzed by GC using hexadecane as internal standard.

Typical procedure for the thiazolylidene-catalysed cleavage of $\alpha$-hydroxyketone to aldehydes by reactive distillation:

In a 25-mL bottom flask, under an argon atmosphere, $\mathrm{K}_{2} \mathrm{CO}_{3}$ (1.2 mmol, $165.8 \mathrm{mg}, 10 \mathrm{~mol} \%$ ), 3-butyl-4,5-dimethylthiazol- 3-ium triflate 25 (766.5 mg, $2.4 \mathrm{mmol}, 20 \mathrm{~mol} \%)$ and $\alpha$ hydroxyketone $(12 \mathrm{mmol})$ were added and the distillation setup was installed. Then, the mixture was heated at $180^{\circ} \mathrm{C}$ (oil bath pre-heated at $180^{\circ} \mathrm{C}$ ) under reduced pressure (vacuum $=1-3$ mbar, except for the case of $\alpha$-hydroxyketones 4 and 35). The distillate was collected, weighted and analysed by GC, using $n$-hexadecane as internal standard. The residue was also weighted and analyzed by GC and NMR. If needed, the aldehydes could be further purified by flash chromatography (cyclohexane/EtOAc 99.8:0.2 $\rightarrow$ 95:5).

\section{Acknowledgements}

The authors thank the SAS PIVERT for a Ph.D. grant to N. D. Vu (GENESYS program - project WP3P21-Bioaldehydes). This work was performed in partnership with the SAS PIVERT, within the frame of the French Institute for the Energy Transition (Institut pour la Transition Energétique (ITE) P. I. V. E. R. T. (http://www.institut-pivert.com)) selected as an Investment for the Future ("Investissements d'Avenir"). This work was supported, as part of the Investments for the Future, by the French Government under the reference ANR-001-01. The authors would also like to thank Dr E. Jeanneau (ISA-Lyon) for X-Ray analysis and Dr C. Negrell (ENSCM-Montpellier) for TGA analyses.

Keywords: Vegetable oils $•$ Thiazolium salts $\cdot \alpha$-hydroxyketones - Retro-benzoin condensation • Aldehydes

[1] A. Corma, S. Iborra, A. Velty, Chem. Rev. 2007, 107, 2411-2502

[2] http://www.rea.co.uk/rea/en/markets/oilsandfats/worldproduction, 2015.

[3] a) F. Ma, M. A. Hanna, Bioresour. Technol. 1999, 70, 1-15; b) A Srivastava, R. Prasad, Renewable Sustainable Energy Rev. 2000, 4 111-13; c) A. Demirbas, Appl. Energy 2011, 88, 17-28.

[4] a) U. Biermann, W. Friedt, S. Lang, W. Lìns, G. Machmiller, J. O Metzger, M. Rìsch gen. Klaas, H. J. Sch.fer, M. P. Schneider, Angew. Chem. Int. Ed. 2000, 39, 2206-2224; Angew. Chem. 2000, 112, 22922310; b) U. Biermann, U. Bornscheuer, M. A. R. Meier, J. O. Metzger, 
H. J. Sch.fer, Angew. Chem. Int. Ed. 2011, 50, 3854-3871; Angew. Chem. 2011, 123, 3938-3956; c) M. A. R. Meier, J. O. Metzger, U. S Schubert, Chem. Soc. Rev. 2007, 36, 1788-1802; d) Y. Xia, R. C Larock, Green Chem. 2010, 12, 1893-1909.

[5] J. M. Fraile, J. I. García, C. I. Herrerías, E. Pires, Synthesis, 2017, 49, 1444-1460.

[6] For a review about hydroformylation of oleochemicals, see: T. Vanbésien, E. Monflier, F. Hapiot, Eur. J. Lipid Sci. Technol., 2016, 118 26-35.

[7] a) D. Mandelli, Y. N. Kozlov, W. A. Carvalho, G. B. Shul'pin, Catal. Commun. 2012, 26, 93-97; b) B.-J. Kollbe Ahn, S. Kraft, X. S. Sun, J. Agric. Food Chem. 2012, 60, 2179-2189.

[8] a) B.-J. Kollbe Ahn, S. Kraftb, X. S. Sun, J. Mater. Chem. 2011, 21, 9498; b) M. Dierker, H. J. Schäfer, Eur. J. Lipid Sci. Technol. 2010, 112 122-136.

[9] K. M. Doll, G. B. Bantchev, R. E. Murray, ACS Sustainable Chem. Eng. 2013, 1, 39-45.

[10] a) N. D. Vu, B. Guicheret, N. Duguet, E. Metay, M. Lemaire, Green Chem. 2017, 19, 3390-3399; b) S. Fürmeier, J. O. Metzger, Eur. J. Org Chem. 2003, 885-893; c) E. Brousse, D. Lefort, C. R. Acad. Sc. Paris 1965, 261, groupe 8, 1990-1991.

[11] a) J. Langanke, L. Greiner, W. Leitner, Green Chem., 2013, 15, 1173 1182 ; b) N. Tenhumberg, H. Büttner, B. Schäffner, D. Kruse, M Blumensteinc, T. Werner Green Chem. 2016, 18, 3775-3788; c) H. Büttner, C. Grimmer, J. Steinbauer, T. Werner, ACS Sustainable Chem. Eng. 2016, 4, 4805-4814.

[12] T. Vanbésien, E. Monflier, F. Hapiot, Green Chem. 2016, 18, 66876694.

[13] For our contribution on the reductive alkylation of polyols with aldehydes, see: a) Y. Shi, W. Dayoub, A. Favre-Réguillon, G.-R. Chen, M. Lemaire, Tetrahedron Lett, 2009, 50, 6891-6893; b) Y. Shi, W Dayoub, G.-R. Chen, M. Lemaire, Green Chem. 2010, 12, 2189-2195; c) C. Gozlan, R. Lafon, N. Duguet, A. Redl, M. Lemaire, RSC Adv. 2014, 4, 50653-50661; d) Sutter, M.; Da Silva, E.; Duguet, N.; Raoul, Y.; Métay, E.; Lemaire, M. Chem. Rev. 2015, 115, 8609-8651; e) Gozlan, C.; Deruer, E.; Duclos, M.-C.; Molinier, V.; Aubry, J.-M.; Redl, A.; Duguet, N.; Lemaire, M. Green Chem. 2016, 18, 1994-2004; f) Belmessieri, D.; Gozlan, C.; Duclos, M.-C.; Molinier, V.; Aubry, J.-M.; Dumitrescu, O.; Lina, G.; Redl, A.; Duguet, N.; Lemaire, M. Eur. J. Med. Chem. 2017, 128, 98-106; g) Belmessieri, D.; Gozlan, C.; Duclos, M. C.; Dumitrescu, O.; Lina, G.; Redl, A.; Duguet, N.; Lemaire, M. Bioorg Med. Chem. Lett. 2017, 27, 4660-4663.

[14] N. D. Spiccia, E. Border, J. Illesinghe, W. R. Jackson, A. J. Robinson, Synthesis 2013, 45, 1683-1688.

[15] a) G. S. Forman, R. M. Bellabarb, R. P. Tooze, A. M. Z. Slawin, R. Karch, R. Winde, J. Organomet. Chem. 2006, 691, 5513-5516; b) K. A Burdett, L. D. Harris, P. Margl, B. R. Maughon, T. Mokhtar-Zadeh, P. C Saucier, E. P. Wasserman, Organometallics 2004, 23, 2027-2047; c) R. M. Thomas, B. K. Keitz, T. M. Champagne, R. H. Grubbs, J. Am. Chem. Soc. 2011, 133, 7490-7496; d) J. C. Mol, Green Chem. 2002, 4, 5-13.

[16] a) A. Behr, A. J. Vorholt. Hydroformylation and Related Reactions of Renewable Resources. In: Meier M., Weckhuysen B., Bruijnincx P. (eds) Organometallics and Renewables. Top. Organomet. Chem., 2012 39, 103-128. Springer, Berlin, Heidelberg; b) M. Furst, V. Korkmaz, T. Gaide, T. Seidensticker, A. Behr, A. J. Vorhold, ChemCatChem, 2017 9, 4319-4323.

[17] a) K. Louis, L. Vivier, J.-M. Clacens, M. Brandhorst, J.-L. Dubois, K. De Oliveira Vigier, Y. Pouilloux, Green Chem. 2014, 16, 96-101; b) T. S Omonov, E. Kharraz, P. Foleyb, J. M. Curtis, RSC Adv. 2014, 4 53617-53627; c) M. D. Lundin, A. M. Danby, G. R. Akien, T. P. Binder, D. H. Busch, B. Subramaniam, ACS Sustainable Chem. Eng. 2015, 3 3307-3314.

[18] a) G. Maerker, E. T. Haeberer, U.S. Patent, US 3405149, 1968; b) S. Mithran, A. S. Subbaraman, Molecules, 1999, 4, 159-164.

[19] N. J. Turner, Curr. Opin. Biotechnol. 2000, 11, 527-531.
[20] T. Saravanan, M.-L. Reif, D. Yi, M. Lorillière, F. Charmantray, L. Hecquet, W.-D. Fessner. Green Chem. 19, 481-489.

[21] For reviews on NHC catalysis including benzoin condensation, see: a) X. Bugaut, F. Glorius, Chem. Soc. Rev. 2012, 41, 3511-3522; b) C. D Campbell, K. B. Ling, A. D. Smith, in N-Heterocyclic Carbenes in Transition Metal Catalysis and Organocatalysis (Ed. C. S. J. Cazin), Springer, Netherlands, 2011, pp. 263-297; c) P.-C. Chiang, J. W. Bode, in N-Heterocyclic Carbenes: From Laboratory Curiosities to Efficient Synthetic Tools (Ed. S. Díez-González), Royal Society of Chemistry, Cambridge, 2010, pp. 339-445; d) E. M. Phillips, A. Chan, K. A. Scheidt, Aldrichimica Acta 2009, 42, 55-66; e) D. Enders, O. Niemeier, A. Henseler, Chem. Rev. 2007, 107, 5606-5655; f) N. Marion, S. DíezGonzález, S. P. Nolan, Angew. Chem. Int. Ed. 2007, 46, 2988-3000.

[22] SciFinder returns 1230 references for the concept of "benzoin condensation" while only 13 references were found using "retrobenzoin" as keywords (December $\left.1^{\text {st }}, 2017\right)$. Duplicates were removed for each search

[23] a) A. Miyashita, Y. Suzuki, Y. Okumura, T. Higashino, Chem. Pharm. Bull. 1996, 44, 252-254; b) A. Miyashita, Y. Suzuki, Y. Okumura, K. Iwamoto, T. Higashino, Chem. Pharm. Bull. 1998, 46, 6-11; c) Y. Suzuki, Y. Takemura, K. Iwamoto, T. Higashino, A. Miyashita, Chem. Pharm. Bull. 1998, 46, 199-206.

[24] J. Zhang, C. Xing, B. Tiwari, Y. R. Chi, J. Am. Chem. Soc. 2013, 135 8113-8116.

[25] E. Deruer, N. Duguet, M. Lemaire, ChemSusChem 2015, 8, 2481-2486

[26] $\mathrm{K}_{2} \mathrm{CO}_{3}$ was previously identified as the most suitable base for this retro benzoin process. Moreover, the use of microwaves was privileged for the optimization as preliminary experiments have shown that microwave heating was more efficient and faster than traditional heating. Similar observation was made by Chi et al. for the retrobenzoin condensation of carbohydrate derivatives (see reference 24).

[27] A. Fulias, G. Vlase, T. Vlase, D. Onetiu, N. Doca and I. Ledeti, J. Therm Anal. Calorim., 2014, 118, 1033-1038.

[28] a) N. Shimahara, N. Nakajima and H. Hirano, Chem. Pharm. Bull., 1974 22, 2081-2085; b) N. Shimahara, H. Asakawa, Y. Kawamatsu and H. Hirano, Chem. Pharm. Bull., 1974, 22, 2086-2090.

[29] a) W. H. Awad, J. W. Gilman, M. Nyden, R. H. Harris, Jr., T. E. Sutto, J. Callahan, P. C. Trulove, H. C. DeLong and D. M. Fox, Thermochim Acta, 2004, 409, 3-11; b) H. Ohtani, S. Ishimura and M. Kumai, Anal. Sci., 2008, 24, 1335-1340.

[30] Methyl iodide was not detected, even in the liquid nitrogen trap before the pump as it is too volatile. So far, it could not be ruled out that methyl iodide could react with a nucleophile, e.g. the $\mathrm{OH}$ group of the $\alpha$ hydroxyketone, in the reaction media. However, the corresponding methylated $\alpha$-hydroxyketone was not observed in the GC chromatograms.

[31] M. T. Clough, K. Geyer, P. A. Hunt, J. Mertes and T. Welton, Phys Chem. Chem. Phys. 2013, 15, 20480-20495.

[32] For a review about the thermal stability of ionic liquids, see: C. Maton, N. De Vos, C. V. Stevens, Chem. Soc. Rev. 2013, 42, 5963-5977.

[33] Q. Yan, H. Zang, C. Wu, J. Feng, M. Li, M. Zhang, L.Wang, B. Cheng, J. Mol. Liq. 2015, 204, 156-161.

[34] J. G. Huddleston, A. E. Visser, W. M. Reichert, H. D. Willauer, G. A Broker, R. D. Rogers, Green Chem. 2001, 3, 156-164.

[35] For examples of self-metathesis of methyl oleate, see: a) J. C. Mol Green Chem. 2002, 4, 5-13; b) A. Kajetanowicz, A. Sytniczuk and K Grela, Green Chem. 2014, 16, 1579-1585. 
Entry for the Table of Contents (Please choose one layout)

Layout 1:

\section{FULL PAPER}

Text for Table of Contents

Layout 2:

\section{FULL PAPER}

((Insert TOC Graphic here: max. width: $5.5 \mathrm{~cm}$; max. height: $5.0 \mathrm{~cm})$ )

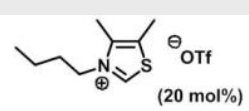

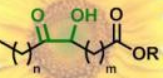
$\underset{\text { neat, } 180^{\circ} \mathrm{C}, 1-3 \mathrm{mbar}}{\stackrel{\mathrm{K}_{2} \mathrm{CO}_{3}(10 \mathrm{~mol} \%)}{\longleftarrow}}$

$15 \mathrm{~min}$
$\mathrm{H}_{\mathrm{n}}^{\mathrm{O}}+\mathrm{H}_{\mathrm{H}} \mathrm{O}_{\mathrm{m}}^{\mathrm{O}}$

Bio-based aldehydes
Nam Duc Vu, Souleymane Bah, Elsa Deruer, Nicolas Duguet ${ }^{*}$ and Marc Lemaire*

Page No. - Page No.

Robust organocatalysts for the cleavage of vegetable oil derivatives to aldehydes through retro-benzoin condensation 